\title{
The Imparative of Repositioning Nigeria's Development Initiative Through Agriculture, The Neglected Path
}

\author{
Dr. Charles Onuora Okwuwa \\ Department of Sociology \\ Ibrahim Badamasi Babangida University \\ Niger State, Nigeria
}

\begin{abstract}
Through series of age-long interactions and experimentations, agricultural production with its associated technologies, has always been the pivot for rural and general socioeconomic development. By implication, at least among the Third World countries, agriculture, among other sectors and depending on how it is managed, addresses poverty and unemployment challenges. Since antiquity, Nigeria has practiced agriculture, yet rising food insecurity, unemployment, poverty and stagnated development prevail. These are reversible with adoption of the UN 2030 Sustainable Development Goals (UN, 2015). The challenge to social science prompted this empirical research in Lapai community with the aim of interrogating Nigeria's agricultural practices, issues and prospects towards widening fact based knowledge for enhanced and beneficial agricultural production. The research relied on both quantitative and qualitative methods and generated data from famers in the locality. Among the findings are that systemic exclusive governance and associated impunity, waste, and leadership failure, among others, stagnate agricultural production, grow poverty, unemployment and socio-economic development crisis. Respondents identify government and culture as the sources of the country's failure in agricultural production and related socioeconomic problems and also hold the view that these forces should lead the deconstruction of the problem. Respondents view grassroots attention to farmers as key in developing Nigeria. Among the recommendations are strategic inclusiveness of farmers and all stakeholders in agricultural planning and implementation, liberalized extension services to farmers including financing, training, tools and seedlings.
\end{abstract}

Key words: Poverty, inclusion, natural resources, training, food security

\section{INTRODUCTION}

Agricultural practice is a worldwide set of economic activities geared towards food production and other value chain derivatives for human survival. It has metamorphosed into various developmental stages and technologies. The Neolithic revolution, sometimes called Agricultural Revolution, was the widespread transition, beginning about 12,000 years ago, of human societies from lifestyles based on foraging to lifestyles based on farming and herding (Kotak, 2015). Hitherto, man lived for millions of years surviving on hunting and gathering in a world of extreme cold climate and life threats from wild animals and savages, contrasting modern day relative safety derived from national and international statutes.

Shift from foraging to food production was gradual as both technologies existed side by side, at least initially. Food production heralded sedentary life and assurance of food security from expected harvests, after planting. Smith (2018) argues that for more than a million years, our distant ancestors were hunter-gathers, relying exclusively on gathering wild plants and hunting wild animals for food. He observes further that over a span of only five millennia, from 10,000 to 5,000 years ago, dramatic changes took place in this long standing way of life, as many human societies, in different parts of the world domesticated a variety of plants and 
animals. By 10,000 BP, domesticated plants and animals were part of broad spectrum of resources used by Middle Easterners (Bellwood, 2005).

Africa practiced agriculture along other world zones in early times and formed a valuable resource base of the economy. Agriculture began in the Upper Niger area of the Mande speaking peoples, about 5,000 BC as yam was cultivated at that period as a result of developments and connections with other parts of the world, globalization in antiquity. Asian yams, coco yams, bananas and plantains reached Africa by way of the Near East between the $1^{\text {st }}$ and $8^{\text {th }}$ century AD. Maize, cassava, groundnuts, tobacco and later cocoa as well as varieties of fruits came principally from South America (Murdock, 1959). The basic methods of cultivation of crops in traditional African society involved shifting cultivation, rotational bush fallow, rotational planted fallow, mixed farming, permanent cultivation, tree cultivation and flood land and irrigation farming and practiced as far back as $16^{\text {th }}$ century (Ugboaja, 2005).

Agriculture is directly and indirectly catalytic in national development outcomes, and hence critical in employment generation and poverty reduction. As derivatives, effective agricultural value chain provides qualitative life for citizens through good nutrition, direct employment for almost all citizens including the elderly like retirees, poverty reduction, industrial raw materials, promotes individuals and particularly women and children's health, and other benefits. An economy with robust and resilient agricultural policies and practices is predictably imbued with absorptive capacities for wealth creation and hence development. Agriculture was catalytic to Britain's Industrial Revolution. This is not the case with Nigeria.

The Nigerian economy, from precolonial to the post-colonial era is primarily agrarian where land is collectively owned and controlled by families, in most cases, headed by men. Almost everybody is a farmer, either fulltime or part-time. In Nigeria today, some public and private sector workers, retirees and other categories practice agriculture around their residences by engaging in crop and animal production. Animal production includes raising poultry, fish hatcheries, grass-cutter, rabbit and snail production, among others, using both local and modern technologies. Nigeria's agriculture to date is mainly subsistence and traditional.

Presently, Nigeria is mired in extreme hunger and poverty. Citing the Brooklyn Institute for Social Research (2018), the Vanguard newspaper of 25 June reports: Our trajectories suggest that Nigeria would have about 87 million people in extreme poverty compared with India's 73 million. Despite the fact that agriculture has contributed much to the modern Nigerian economy, the sector suffers from extreme low productivity, reflecting reliance on antiquated methods (Sanusi, 2010), Nigeria's former Central Bank Governor. He observes that agricultural production rose by 28 percent in the 1990s as well as per capita output during the same decade. He concludes that agriculture has failed to keep pace with Nigeria's rapid population growth so that the country which once exported food, now relies on imports to sustain itself.

The Nigerian agricultural sector was in past decades, the biggest sector in the economy. But now the sector just contributes only 23 percent to the country's Gross Domestic Products (GDP) (Osikoya, 2016). The global challenge of food insecurity and poverty, among others, prompted the establishment of the United Nations 2030 SDGs in 2015 with the main them: A call for action to change our world of which ending hunger and achieving food security, featured among its seventeen goals. Zakari Fusheni, a nutrition specialist in UNICEF Abuja office, on March 23, 2016, disclosed: Over 1.6 million Nigerian children are suffering from acute malnutrition. The children are nine times likely to die than normal children and if nothing is done about it, we will likely lose 300,000 of these children. 
This is a social science challenge that should interrogate official policies and programmes regarding agriculture as a vital pillar of the economy that integrally drives development. The concerns in this empirical research include the extent state functions respond to the basic needs of the general population, in Maslow's typology, ranking food and related items as basics for human survival. These concerns motivated the empirical research that relies on quantitative survey, utilizing questionnaire, interviews and field notes to generate data based policy recommendations.

\section{Research Objective}

The general aim of the research is to investigate the dimensions of agricultural practice in Nigeria from rural farmer's perspective with a view to guiding policy programming through fact based formulations that target eliminating food insecurity and priming national development.

\section{The specific objectives include:}

i. Examine the quality of life of the Nigerian local farmer in agricultural practice.

ii. Evaluate the place of rural agriculture as a governance imperative

iii. Identify local farmers' participation in the agriculture sub sector of the economy.

iv. Identify the farmer's benefits from agricultural resource allocation and consumption.

v. Identify the challenges of effective participation of local farmers in agricultural practice.

vi. Evaluate the perceptions of respondents on government's agricultural policies.

vii. Appraise the perceptions of respondents on how to improve rural agriculture.

\section{Research questions}

i. What is the quality of life of the Nigerian local farmer in agricultural practice?

ii. What is the quality of rural agriculture as a governance imperative?

iii. To what extent do local farmers participate in the agriculture sub sector of the economy?

iv. What do the farmer's benefit from agricultural resource allocation and consumption.

v. What are the challenges of effective participation of local farmers in agricultural practice?

vi. How do respondents perceive government's agricultural policies?

vii. How can rural agriculture be improved.

\section{Justification for the study}

The research findings will shed light on the real situation of agricultural practice in Nigeria and establish the extent official pronouncement correlate with actual existential lives of individuals. The findings will provide evidences of the right direction to follow in resolving agricultural development challenges by government, corporate and individual caregivers. It will highlight what the victims consider as critical needs and what in their perception constitutes meaningful interventions. Overall, the research will contribute to knowledge to stakeholders; it will form a reference material to government, corporate bodies, individual caregivers, scholars, policy makers, administrators and the public.

\section{LITERATURE REVIEW}

The review focuses on the conceptual framework that links agriculture and development. It draws a parallel from the United Nations 2030 SDGs related correlation of planning effectiveness that highlights inclusiveness in agricultural policy framework on one hand and on the other hand, resultant outcomes of local farming and farmers' development. It entails improvements that increase farmer productivity, living standards, poverty reduction and food security with acceptable nutrition level. Other benefits are availability of raw materials, reduced food importation, employment generation, and others like social conflict reduction. Development is individual freedoms, opportunities, access to state resources like political 
power, education, leisure, health and all aspects of social actions. This perspective could be linked, as an example, with England's evolutionary and subsequently industrial revolutions that changed the course of world history.

In England, prior to industrial revolution, cottage industries were common when a large proportion of the population engaged in agriculture because the farmers and their families had time and motivation to earn additional income during that part of the year when there was little farming work (Raj, 2012). Precolonial Nigerian societies equally had similar practices. Additional to farming, families and communities engaged in crafts which popularized the Bini art works that produced Queen Idia bronze piece, now in the London Museum, Ife, Igbo-Ukwu, Nok, Bida metal works and the famous Kano leather and cotton manufacturing industries, and applied local technologies. It is estimated that 90 percent of African art works are in Europe (CNN, 2018).These include Nigerian works.

Ozo Eson (2012) observes that agriculture was the major means of livelihood of the traditional pre-colonial economy operating along non- agricultural activities that included long-distance trade which was carried out on part -time basis, as part of the economy. In the Precolonial SubSaharan Africa, internal and external trade on agricultural, manufactured and 'human goods' was developed, a precursor of mercantilism and present globalization. Thus, like pre-industrial England, some traditional Nigerian communities developed rudimentary technologies that were capable of integration with colonial technologies towards gradual rural agricultural development. Today, they form neglected development assets. The AGOA (2000) initiative is a continuing elongation of such pristine political economy.

Presently, Nigeria faces food insecurity as a result of apparent neglect of rural agricultural prioritization. According to NEEDS (2004), Nigeria's rich human and natural resource endowments give it the potential to become Africa's largest economy. Much of its potentials has remained untapped, putting attainment of the Millennium Development Goals by 2015 in jeopardy. Raj (2012) posits: One of the factors that helped the development of cottage industry was the enclosing of the common lands in Europe, land set aside for the common people to raise crops and graze their livestock. The author observes that the cottage industry had the feature of businessmen travelling around and buying raw materials for processing. Also such businessmen collected the finished products for further process or resale. As an example of this development, he gave the textile industry which processing involved carding, spinning and weaving that engaged children, women and men. However, the Nigeria's local farmers hardly access agricultural funding from other financial outlets, among other reasons, due to their nonavailability, rigid conditions for accessing them, among the mass illiterate populations. Hence data confirms financial exclusion report that Nigeria's $46.6 \%$ females and $36.8 \%$ males are financially excluded (Zenith Economic Quarterly, 2017).

Thus, the structural arrangement of the England's political economy was ab initio planned, and accommodative of the peasantry and hence facilitated rural and industrial revolution that subsequently reverberated globally. Today, Nigeria is faced with major social problems of Boko Haram and Niger Delta insurgencies as well as menacing herdsmen and indigenous farmers' bloody encounters which have poverty, neglect and in a wider context, social exclusion as the main causative factors.

The industrialization friendly England's environment further facilitated the emergence of feudalism which defined an unequal economic relationship between usually powerful land owners (lords) and vassals and also the manor system which though existed within the feudal system, but was primarily a rural economy transformation approach. The innovations shaped 
the basic dynamics of industrial revolution originating from 18 century England that later spread to Western Europe and North America. The environment was a structured and inclusive economic system which factored rural economy into the entire England's political economy and thus empowered the local famers, improved their incomes relative to urban affluence and created an enabling environment for rapid rural development that facilitated the industrial revolution that changed world history.

The centuries' long England's agricultural and general industrialization inclusiveness is such that aligns with Max Weber's rationality principles as a development model that emphasizes specialized technical competences, professionalism, impersonal relationships, goal directed social actions, division of labor, strong institutions and efficiency, the bedrock of modernity. According to Giddens (2003), in Weber's view, the Industrial Revolution and rise of capitalism were proof of a large trend towards rationalization, the organization of social and economic life according to principles of efficiency and basis of technical knowledge. Development without the foundation of robust agriculture in a transitional society like Nigeria hangs on a precipice.

In reality, socio-economic advancement today is a product of efficiency and specialized technical and professional skills, knowledge and attitudes more than of superstition and related non-fact based general knowledge. England's industrial revolution, among others, stood on a solid agricultural base alongside inventions and activities that drew heavily from Weber's rationality principles. Raj (2012) captures it thus:

The industrial revolution is one of the most important events in human history which witnessed changes in agriculture, manufacturing, mining and transportation.... In the $18^{\text {th }}$ century, Great Britain experienced a massive increase in agricultural productivity known as the British Agricultural Revolution which enabled an unprecedented population growth, freeing a significant percentage of the workforce from farming, to drive the industrial revolution ... (Raj, 2012).

Advanced technologies may have universal applications but they do harbor dislocations and developmental setbacks resulting from cultural lag in developing economies. England's model could guide Nigeria through filtered adoption. As examples, irrespective of cultural imperatives, aspects such as use of pesticides, hybrid seeds and seedlings, agricultural machineries, modern dam system, food processing and preservation innovations, gender balanced resource allocation and utilization and female gender inputs in agricultural policy and practice programming could be adopted from the Anglo agricultural and even any other model identified as useful. However, Nigeria did not go deep to create a friendly rural farming environment to improve agriculture and development.

In order to explain the missing link, let us analyze the features of Nigeria's agricultural practice. Agriculture was and is still the first organized mode of economic production which initially targeted availability of food for human survival aside proceeds of hunting and gathering. It can involve a whole family, or community, with increasing population, unlike hunting and gathering which could be an individual activity with sparse population. Nigeria is primarily an agrarian society with predominantly arable land for tubers, grains and poultry production. It is the source of livelihood particularly for rural dwellers who fish the waters and farm the lands. Almost everybody or family practices agriculture which makes the economy mono-cultural. This justifies why governance should capitalize on this industry's value chain as a spring board for inclusive socio-economic development capable of yielding employment, poverty and inequality reduction. These form the pillars of development, in Seer's (1996) perspective, which are concerns that target reduction of poverty, inequality and unemployment. 
But Okafor (2012), dissecting Nigeria's economy states: Land is the major means of production; primacy of family in the allocation of role in production activities; subsistence agriculture as the mainstay of the economy; little or limited division of labor and specialization and use of simple or crude implements and tools for production. Otite and Ogionwo (2006) posit that the procedure of carrying out economic activities is passed down from one generation to another, while young men and women are made to emulate their parents. The same production methods are used year in, year out, and the mode of production is simple. It is therefore unexpected that these extant methods by majority of Nigerian farmers would yield food sufficiency. This is because the simple mode of production cannot meet the rising population with its demographic complexity.

These endogenous practices could be integrated within the foregoing facts of the Anglo agricultural development model for improved food production and national development. Nigeria was once famed for the production of groundnuts, cocoa, palm oil, cotton, rubber and hides and skins during the colonial and post independent period but it literary abandoned agriculture due to its decade's long dependence on revenue derived from petroleum export. Crusoe (2016) quoting the Nigerian Export Promotion Council observes that Nigeria's oil revenue accounts for about 90 percent of the total merchandise and more than 80 percent of the total revenue.

Sanusi (2010) opines that a feature of the sector is the dominance of peasant farmers and their reliance on rudimentary farm equipment and low technology. A feature of the agricultural sector is undercapitalization which results in low yields and declining output, among others. Nigeria cannot develop in that way. Broadly put, increases in agricultural productivity are central to growth, income distribution, improved food security, and alleviation of poverty in rural Africa (FA0, 2002). Nigeria spends at least N1 trillion annually importing rice, sugar, wheat and fish (Oxfam International (2017), citing a World Bank Report of 2010.The enormity of the challenge is that with such a trend, Nigeria must have been discouraging and impoverishing the farmers, micro, small and medium enterprises, as well as large food and related manufacturers.

The Daily Trust Board of Economist (2018) advised the Federal Government to orient the national budget towards rural areas as a way of trimming the capital budget in line with currents realities. It recommends that the government should do that in collaboration with the state and local governments, with built in mechanisms for effective coordination, accountability and transparency to ensure greater value for money in budget implementation. This recommendation is apt. Building up the rural economy, including human quality and physical facilities upgrade, means shaping an economy capable of poverty, unemployment and rural-urban migration reduction. In the informal sector, it can trigger manufacturing and economic diversification with availability of raw materials, consumption and aggregate demand, employment, family welfare, maternal and infant health and wellbeing and overall national development with decreasing social conflicts and deviance.

Acemoglu and Robinson (2013) devised a model that views inclusive or exclusive institutions in governance as the reasons why nations prosper or fail. They contend that inclusive institutions based on transparency, openness, freedom, social justice, strong institutions, egalitarianism and the like are the sources of development and wealth while extractive institutions that apply impunity, weak institutions, organized crime, censorship, defense of elite interests and values, corruption, monopolies, centralization and restrictions are the facilitators of poverty and underdevelopment. Based on a fifteen year research on why nations fail that broadly catalogued the origins of power, prosperity and poverty, the authors applied 
the model to explain the poverty and wealth of many nations. Unlike the cases of some developing countries like Zimbabwe, Gambia, and many others that are mired in exclusive institutions, they identified Brazil, as a fast developing economy with increasing inclusive institutions.

In Brazil, since 1990, economic growth has been rapid, with the population in poverty falling from $45 \%$ to $30 \%$ in 2006. Inequality, which rose rapidly under the military, has fallen sharply, and there has been huge expansion of education...average years of schooling of the population increasing from six in 1995 to eight in 2006, now a part of the BRICS Nations (Brazil, Russia, India and China) ...Acemoglu and Robinson (2013).

The authors contend that inequality, which rose rapidly under the military, fell sharply with huge expansion of education and poverty reduction due to its inclusive policies.

Thus, a Nigerian governance style that orients towards exclusive institutions can transform its rural economy with such outcomes as improved farmers' living standards, food sufficiency, aggregate demand and consumption as well as employment through inclusiveness.

\section{Location of study}

\section{RESEARCH DESIGN}

The research was carried out in Lapai, Headquarters of Lapai Local Government of Niger Sate. As an emirate, its traditional ruler is an Emir who, as a cultural custodian, wields much influence in governance of the area which constitutionally rests with the local government. Lapai has a projected 2016 population figure of 3, 56.4,100 (Wikipedia, 2016). Lapai and surrounding towns and villages are agrarian and live off the sprawling plains, with good climate that supports both animal and crop production. The population comprise virtually the indigenous Nupe ethnic group who practice traditional agriculture, commerce and low skill professions.

Lapai hosts a few government offices, a general hospital, a large central weekly Tuesday only market and the government owned young but thriving IBBU which was established in 2006. It has, among others, the Faculty of Agriculture which operates a commercial and successful ranch and farm. About fifty kilometers to the north east lies Paiko, famed as the largest yam market in Nigeria which tends to boost agriculture in the state.

\section{Population sample and method of sample selection}

Samples were taken from the central market which is considered ideal to locate the farmers of both genders. Specifically, only crops and livestock adult sellers who identified themselves as famers or part of the agribusiness chain were purposively selected to meet the purpose of the research. Youths were purposely and deliberately selected since they were more likely to have opinions on the subject. Out of Lapai's 2016 projected 3, 56.4,100 people, a total of 130 sample was purposefully selected.

Six opinion leaders were interviewed by the researcher to improve the quality of the research with free comments outside the structured instrument used. They are:

i. Olorunsanya, A.O., 62 years, a professor of agriculture, former Dean, Faculty of Agriculture, Ibrahim Badamasi Babangida University (IBBU), Lapai, and presently, Dean of The Post School, same university. He is married with children.

ii. Mohammed Salihu, 49 years, a Bida Polytechnic and IBBU, Lapai, graduate, and an employee of Lapai Local Government, Lapai. He is married with children.

iii. Audu Farida, 30 years, a Lapai based trader, and married with children,

iv. Akeem Toyin, 32 years, a graduate and businessman. 
v. Mohammed Abubakar, 45 years, a farmer married with three children.

vi. Kolo John, 39 years, an agriculture graduate, Lapai based farmer, and married with two children.

The opinion leaders were sampled because of their experiences in Lapai's environment.

\section{Data collection}

Data was collected through the use of questionnaires, interview guide and personal observations. The questionnaire comprises Section A and Section B. Section A targeted the respondents' bio-data. Section B targeted respondents' perceptions and expectations relative to the research objectives. The questionnaires contained closed and open-ended questions. The interview guide comprised five open-ended questions and based on the research objectives.

A Validity and reliability test was done at the Lapai weekly Tuesday market. The in-depth interview was conducted by the researcher alone who taped recorded respondents' responses and made field notes also. Only 110 (84.6 percent) questionnaires were returned as respondents cited general insecurity and need for prompt sales as limitations for the low returns. Three sociology trained research assistants, fluent in Lapai's common Hausa, Gbagi and Nupe languages, assisted in the distribution and collection of the questionnaires. The interviews with opinion leaders were conducted in Ibrahim Badamasi Babangida University and Lapai's weekly Tuesday market. Data collection through the questionnaire and in-depth interviews were done in September, 2018.

The researcher collated and analyzed the 110 questionnaires, using percentages and frequencies.

\section{DATA ANALYSIS}

Data analysis is presented based on respondents' bio-data, then followed by their responses that derive from the research objectives. The relevant findings of both the quantitative and qualitative data are treated under the table data analysis section, with a summary of the qualitative data lastly.

Table 1. Respondents' bio data

\begin{tabular}{|c|c|c|c|c|c|c|c|c|}
\hline Gender & Freq & $\%$ & Religion & Freq. & $\%$ & Marital status & Freq. & $\%$ \\
\hline Male & 74 & 67.3 & Christianity & 89 & 80.9 & Married & 88 & 80.0 \\
\hline Female & 36 & 32.7 & Muslim & 21 & 19.1 & Single & 5 & 4.5 \\
\hline & & 100.0 & African Trad. Religion & & & Separated & 11 & 10.0 \\
\hline Total & 110 & & Total & 110 & 100.0 & $\begin{array}{l}\text { Divorced } \\
\text { Total }\end{array}$ & $\begin{array}{c}6 \\
110\end{array}$ & $\begin{array}{c}5.5 \\
100.0\end{array}$ \\
\hline
\end{tabular}

Legend: Freq=Frequency; Trad=traditional

From above table, 67 percent of the respondents are males. Historically, Nigeria is primarily agrarian whereby land is collectively owned and controlled by families, generally headed by men. With recent economic recession with high level poverty, almost every male adult is a farmer, either fulltime or part-time. Today, increasing public and private sector workers, retirees and other categories, practice agriculture in village lands, and also within and around their compounds, even in urban suburbs. This can justify the male preponderance over females. Majority of the respondents (80) percent are married. 
Okwuwa, C. O. (2019). The Imparative Of Repositioning Nigeria's Development Initiative Through Agriculture, The Neglected Path. Advances in Social Sciences Research Journal, 6(5) 250-264.

Table 2. Respondents bio data; age, education, occupation and income

\begin{tabular}{|c|c|c|c|c|c|c|c|c|c|c|c|}
\hline Age & Freq & $\%$ & Education & Freq & $\%$ & Occupation & Freq. & $\%$ & $\begin{array}{c}\text { Incom } \\
\text { e N } \\
(000)\end{array}$ & Freq & $\%$ \\
\hline$<25$ & 11 & 10.0 & None & 43 & 39.1 & Civil service & 15 & 13.6 & $<50$ & 4 & 3.7 \\
\hline $25-34$ & 16 & 14.6 & Primary & 54 & 49.1 & Fulltime farming & 51 & 46.3 & $51-100$ & 13 & 11.8 \\
\hline $35-44$ & 69 & 62.7 & Secondary & 13 & 11.8 & Artisan/services & 40 & 36.4 & $\begin{array}{c}101- \\
150\end{array}$ & 37 & 33.6 \\
\hline $45+$ & 14 & 12.7 & Tertiary & 00 & 0.0 & Others & 4 & 3.7 & $151+$ & 56 & 50.9 \\
\hline Total & 110 & $\begin{array}{c}100 . \\
0\end{array}$ & & 110 & 100 & Total & 110 & 100 & Total & 110 & 100.0 \\
\hline
\end{tabular}

Legend: Freq.=frequency;

A total of $62.7 \%$ of the targeted respondents fall within the mean age bracket of $35-44$ years. The younger population of below 35 years form only 24.6 percent of the presumed famers. Apparently, the latter are not attracted to Nigeria's generally intensive rural agriculture that employs crude implements. Rather, they are attracted to quick money yielding motor cycle and tricycle transport business and also the trending telecommunications and high demand information and computer technology (ICT) services through business centers and cybercafés that abound in the thriving university town.

Many of the civil servants and artisans engage in farming within the government offices, including the only university in Lapai. All the security guards and some other workers with the Bwari Local Government, farm the office vicinity. Salihu Mohammed, a sociologist and one of the council workers, owns a farm and produces mainly maize and guinea corn. He said: We all do it every year. Some of our retirees still farm here. Poverty situation is serious and we have to cater for our families.

Again, the situation of respondents' very low education(39 and 49 percent with 'no' and 'primary' education only respectively) predispose them to motor cycle and related transport, sale and repair of telecommunications and ICT products, household repairs, fashion and related low occupations, classified under artisans and services. Thus, 36.4 percent engage in such low skilled activities in an agrarian community, leaving only 46.3 percent as full time farmers with equally very low income where only 51 percent earn N151, 000 and above annual income. This amounts (N12, 600 monthly income) is far less than Nigeria's presently challenged decade old N18, 000 monthly income. This confirms Salihu Mohammed's concern situation.

Table 3. Perceived quality of rural life and agriculture as a governance tool

\begin{tabular}{|l|c|c|l|c|c|}
\hline Quality of life & Frequency & Percentage & Quality of rural agric. & Frequency & Percentage \\
\hline Very good & 3 & 2.7 & Very organized & 3 & 2.7 \\
\hline Good & 6 & 5.5 & Organized & 7 & 6.4 \\
\hline Average & 13 & 11.8 & Average & 14 & 12.7 \\
\hline Bad & 65 & 59.1 & Unorganized & 40 & 36.4 \\
\hline Very bad & 23 & 20.9 & Very unorganized & 46 & 41.8 \\
\hline Total & $\mathbf{1 1 0}$ & $\mathbf{1 0 0 . 0}$ & Total & $\mathbf{1 1 0}$ & $\mathbf{1 0 0 . 0}$ \\
\hline
\end{tabular}

Table 3 data reveals that 80 percent of the respondents view their life quality as, at best bad, a reflection of their foregoing bio data. Lapel's rural agriculture is unorganized (36.4 percent) and much unorganized (42 percent), and thus unstructured (78.2 percent). The farmers are socially excluded in developmental processes. Many developing countries, including Nigeria, have lagged in creating the basic elements of such an ecosystem where economic growth and social inclusion feed each other, thus missing an opportunity to include more of their 
populations in their developmental process (World Economic Forum, 2017). This is a survey report of 103 countries on Inclusive Development Index (IDI). It employed the ecosystem approach which constitutes the implicit income distribution system or living standards diffusion underpinning modern market economies.

The general opinion of the interviewees on the quality of life of farmers emphasize government neglect of rural farmers. Five of them rate their life quality as very bad. The agricultural graduate interviewee, Kolo John, was very incisive: Very inept leadership has impoverished the rural famers and the whole rural communities. The local farmers only exist. They are living corps.

Table 4. Local farmers' perceptions of their participation level in rural agricultural economy and benefits from resource allocation

\begin{tabular}{|l|c|c|l|c|c|}
\hline $\begin{array}{l}\text { Participation } \\
\text { level }\end{array}$ & Frequency & Percentage & $\begin{array}{l}\text { Benefits: funds, seeds, } \\
\text { fertilizer, trainings } \\
\text { etc.) in a season }\end{array}$ & Frequency & Percentage \\
\hline Very active & 105 & 95.4 & Unfailingly & 0 & 0.0 \\
\hline Active & 4 & 3.7 & Always & 3 & 2.7 \\
\hline Average & 1 & 0.9 & Occasionally & 11 & 10.0 \\
\hline Inactive & 0 & 0.0 & Rarely & 20 & 18.2 \\
\hline Very inactive & 0 & 0.0 & Never & 76 & 69.1 \\
\hline Total & $\mathbf{1 1 0}$ & $\mathbf{1 0 0 . 0}$ & Total & $\mathbf{1 1 0}$ & $\mathbf{1 0 0 . 0}$ \\
\hline
\end{tabular}

From data above, 95 percent of the respondents view themselves as the bedrock of rural agriculture that feed the nation, actively involved in the process. Yet, they have the opinion of not benefitting from the nation's resource allocation in areas of state loans and grants as forms of agricultural financing, provision of improved seeds, fertilizer and other productive inputs for enhanced production. This is reflected in the categories of 'rarely' and 'never' benefitting responses of 18.2 and 69 percent respective responses. It is in consideration of the consequences of rural neglect that the Daily Trust of Economists (2018) advised the various government to reorient their budgets towards rural development to facilitate individual and national development.

Again, majority of the in-depth-interviewees opine: Local farmers feed Nigeria through mass engagement in agriculture. Accordingly, they perceive the farmers as the bedrock of Nigeria's agricultural production. According to Mohammed Abubarkar, Nigeria cannot develop until policy makers recognize the importance of rural famers and communities and develop them. Despite above position, Olorunsanya states that few Lapai famers, generally use the university's only tractor in their farms though majority hardly do so. The latter group is likely the very poor and illiterate farmers who lack confidence and remain rooted in traditionalism.

Table 5. Local farmers' challenges and perceptions of government commitment to rural agriculture

\begin{tabular}{|l|c|c|l|c|c|}
\hline Challenges & Frequency & Percentage & $\begin{array}{l}\text { Perception of govt. } \\
\text { commitment }\end{array}$ & Frequency & Percent \\
\hline Funds & 33 & 30.0 & Very adequate & 4 & 3.7 \\
\hline Power/electricity & 24 & 21.8 & Adequate & 11 & 10.0 \\
\hline Taxation & 8 & 7.3 & Average & 19 & 17.3 \\
\hline Infrastructure(roads, & 9 & 8.2 & Inadequate & 50 & 45.4 \\
\hline $\begin{array}{l}\text { Bureaucracy/corruption } \\
\text { in provision of inputs }\end{array}$ & 36 & 32.7 & Very inadequate & 26 & 23.6 \\
\hline Total & $\mathbf{1 1 0}$ & $\mathbf{1 0 0 . 0}$ & Total & $\mathbf{1 1 0}$ & $\mathbf{1 0 0 . 0}$ \\
\hline
\end{tabular}

Legend: govt=government 
From table 5 data, the local famers encounter various challenges. Bureaucracy and corruption constitute the main hindrance (33 percent) followed by lack of funds (30 percent) and inadequate power supply (22 percent). A total 79 percent view governments' commitment to rural agricultural practices as below average with a consolidated above average responses at 13.7 percent only.

Government policies up till now in the agricultural sector is laughable... There has been minimal implementation of policies to improve the sector. Fertilizer subsidy is yet to improve its availability. Genuine farmers find it difficult to access fertilizer. The importation of hybrid seedlings to boost production is lacking. Dairy production is at its lowest. An estimated 20-30 of yearly harvest is lost during processing. Lack of proper storage facilities expose harvest to pest attacks. Improper storage reduces crop quality (Olawale, 2018).

It is therefore expected that many young ones (below 35 years) will engage in non- agricultural services (36.4 percent) as per table 2 analysis, in an agrarian community.

In support of respondents' views, all the in-depth interviewees stated that bureaucracy, corruption and funds scarcity are the farmers' greatest challenges. Mrs. Audu states: With adequate government funding of rural agriculture, famers can produce more food, train their children and live better.

Table 6. Local farmers needs for improving rural agriculture

\begin{tabular}{|l|c|c|}
\hline Needs for improvement & Frequency & Percentage \\
\hline Materials: farm inputs & 45 & 40.9 \\
\hline Funds & 27 & 24.6 \\
\hline Government-farmers dialogue & 11 & 10.0 \\
\hline Tax exemption & 9 & 8.2 \\
\hline Training/education & 8 & 7.3 \\
\hline Roads & 5 & 4.5 \\
\hline Tractors/machinery & 5 & 4.5 \\
\hline Total & $\mathbf{1 1 0}$ & $\mathbf{1 0 0 . 0}$ \\
\hline
\end{tabular}

From an open ended question, table 6 ranked order data reveal that two main needs are vital; agricultural materials (41 percent, and funds (25 percent). According to the Zenith Economic Quarterly (2016), the Nigerian economy recorded a somewhat weak performance in major indicators in first quarter, 2016. The economy, which, measured by key indicators (including agricultural production), hit its seemingly lowest ebb in two decades by the close of 2015 . It stated: It was further dragged down during the first quarter 2016 by issues of economic policies, aspects of production and distribution of agricultural products, funding, among others. The scenario suggests that a section of the economy, agriculture, essentially the mainstay of the economy, is underperforming due to wrong policies and programmes, particularly funding and materials inadequacy. This challenge should interrogate official policies and programmes regarding agriculture as a vital pillar of the economy, grassroots, and hence, national development.

Towards solving the farmers' needs, majority of the interviewees observe that farmers need funds most to buy agricultural implements, fertilizers, better seeds and yam tubers and hire farm tractors. Further, most of them advised government to curb bureaucracy and corruption that prevent them from accessing good seeds, fertilizers and pesticides which are usually diverted to wealthy bigger farmers. 
Mr. Kolo John, in an in-depth interview states:

Government can develop Nigeria if it is sincere. It should ban smuggling of foods especially rice and prevent their sale in markets. It should allow famers, community or village heads and farmers' cooperate societies' leaders to always dialogue with top government officials here in our localities to properly understand the practice and challenges of rural agriculture.

However, local famers somehow lack the confidence or interest to seek assistance from outside their world. Olorunsanya observes that Lapai famers hardly approach Ibrahim Badamasi Babangida university for expert advice on modern farming, unlike Gudna famers that avail themselves of such opportunities from the university's agricultural extension services. In this case, the university, as part of its community services, can improve their outreach strategies to capture the farmers' interests.

\section{DISCUSSION OF FINDINGS}

The challenges of apparent neglect of rural agricultural stimulation with resultant food insecurity, poverty, rising unemployment, stagnated development and inevitable crime increase necessitated this empirical research in Lapai community with the aim of interrogating Nigeria's agricultural practices, issues and prospects towards widening fact based knowledge for enhanced and beneficial agricultural production. Relying on both quantitative and qualitative methods and generated data from famers in the locality, the finding leads to an inevitable conclusion of deliberate neglect of Nigeria's rural economy where local population appears insulated from the benefits of urban affluence derived mainly from oil export rent.

The young ones survive as virtually illiterates with cheap skills that allows minimal integration into the mainstream economy. With 12 percent possessing only secondary education, 36 percent engaged as artisans and service providers and only 46 percent as full time farmers earning maximum monthly income of N12, 600 (\$35) monthly income, far less that the presently challenged overdue monthly minimum wage of N18, 000, Nigerian can hardly experience peace and development, even with the present oil revenue driven delusive economic growth. The respondents consequently view their life quality as low (80 percent) and the economy as unquestionably unstructured or unorganized.

The respondents rightly view themselves as the bedrock of the economy (95 percent), particularly as primary food producers. They consider themselves as socially excluded (87.3 percent) in the social strata by the almost invisible government presence in the rural agricultural space towards the imperative of organizing the productive system through extension services, provision of tractors, improved seeds and fertilizer provision, among other inputs. It is in consideration of the consequences of rural neglect that the Daily Trust Board of Economists (2018) advised the various government to reorient their budgets towards rural development to facilitate individual and national development.

The existing disservice informs the respondents' two, out of five main challenges; official bureaucracy cum corruption (33 percent), regarding any form of government improvement interventions and unavailability of funds (30 percent) by way of grants and loans. The overall rating is that governments' commitment to rural agriculture is only 13.7 percent adequate and very adequate. Finance connects farmers to opportunity, yet only 4 percent of Nigerian framers access loans to grow their business (Gates,2018).Thus, respondents rightly scaled their needs in the order that ranks materials input 40.9 percent, funds 24.6 percent and Governmentfarmers dialogue 10 percent (accounting for 75.5 percent), as the three most vital, from a seven point need list. 
In summary, the following is articulated as underpinning agricultural under-development in Lapai and Nigeria generally: lack of infrastructures, low agricultural funding, corruption, land ownership structure, drought in the northern part of the country, the drying up of Lake Chad, high illiteracy among the local population, insecurity, lack of power, traditional mode of farming which is also labor intensive, food storage challenges, culture, cross-border smuggling and a host of others. These are man-made and reversible. These factors constitute Nigeria's underdevelopment drivers. Osikoya (2016) observes that the Nigerian agricultural sector was formerly the biggest sector in the economy but now contributes only 23 percent to the country's Gross Domestic Products (GDP). Broadly put, increases in agricultural productivity are central to growth, income distribution, improved food security, and alleviation of poverty in rural Africa (FAO, 2002). Such benefits can result in Nigeria with a reversal of the extant rural agricultural neglect, the conceptual framework of this research.

\section{CONCLUSION}

Neglected rural agriculture, the pristine and yet the present day most practical, pervasive and accessible industry to almost every adult, including the aged, the main food and raw materials sources for manufacturing, symbolizes one of Nigeria's most glaring governance failures. One can conclude that governance is an elitist strategy of keeping Nigeria's critical mass in a cycle of poverty, and too voiceless and powerless to challenge elitism. The dire consequences manifest beyond food insecurity, unemployment, poverty and stagnated development. It precipitates tensions, particularly among communities over scarce resources of water and land, conflicts, forced migration, increasing urban problems, armed robbery, kidnappings of both the poor and the rich as presently prevails, local and foreign business divestment and more general social disorder. These are reversible through reversing observed rural infrastructure and capital deficits that aligns with the United Nations 2030 Sustainable Development Goals with Goal 2 as: End hunger, achieve food security and improved nutrition and promote sustainable agriculture. Means include; by 2030, end hunger and ensure access by all people, in particular the poor and people in vulnerable situations, including infants to safe nutrition and sufficient food all year round.

Agriculture is a purveyor of development and social order. As a universal poverty reduction strategy, it can achieve same effects in Nigeria, like in Brazil, as stated above. Nigeria's export grows at $59.9 \%$ and tax revenue also at $51 \%$ (FG, 2018). The benefits are exclusive of the poor majority and inclusive of an elitist few, a situation that grows a cycle of poverty, frustration, individual and ethnic tensions and conflicts and developmental stagnation. Consequently, the following recommendations are made to reverse the trend that portends an imminent national and regional implosion.

Nigeria can effectively develop its rural agriculture by addressing the salient needs of rural farmers as articulated in this research, among others, thus:

i. Government should provide: Materials like farm inputs, pesticides, herbicides, improved seeds and fertilizers via cooperatives, soft loans and grants to local farmers through cooperatives, government farmers dialogue to deeply understand one another and issues, tax exemption for farmers, practical training of local famers on modern farming techniques, roads infrastructure development and provision of farm machinery at subsidized and cooperative hire-leasing basis.

ii. Depoliticize governance through adherence to the rule of law and equity.

iii. Reduce wastes by pruning personnel appointment, literally perceived as party patronage devices.

vi. Appoint agriculture and finance experts to plan and oversee agricultural revolution initiatives from grassroots to the federal levels. 
v. Re-establishment of marketing boards for easy and quick distribution of farm products.

vi. Establishment of modern silos integrated with solar power system for food storage and price stability to reduce wastes and enhance farmers' revenue.

vii. Abolish the N2 billion monthly security vote allocation to state governors who have the full security services from the armed forces and paramilitary agencies. The Nigerian Court of Appeal recently ruled that the absence of accountability on the use of security votes by state governors amounts to criminal misappropriation.

viii. Effective synergy in public private partnership in Nigeria's agricultural development efforts.

ix. Developing the SME's in all sectors, including agriculture, is vital to reducing the country's unemployment, thereby enhancing diversification from petro dollar and driving economic growth (Osikoya, ,2016).

$\mathrm{x}$. Muster the political will to address all agricultural development policies and plans.

\section{References}

Acemoglu, D. and Robinson, J. A. (2013). Why Nations Fail; the Origins of Power, Prosperity And Poverty, London: Profile Books Ltd.

AGOA (2000). African Growth and Opportunities Act, International Trade Administration. https://www.trade.gov.>agoa

Bellwood, P. S. (2005). The First Farmers: Origins of Agricultural Societies, Malden, MA: Blackwell.

CNN (2018). France to return art works to Benin Republic, CNN News, and 25th November.

Crusoe, O. (2016). NEPC to engage Nigerians in diaspora to drive non-oil exports, economic diversification, Thisday, Friday, March 25, 2016, p.37.

Daily Trust Board of Economists (2018). Reorient Budget towards rural development, Daily Trust, 12 November, 2018, p.1.

Dudley, S. (1969). The Meaning of Development, International Development Review, No. X1, Dec. 1969. pp. 2-6. FAO (2002). Food Insecurity, Poverty and agriculture; A Concept Paper.www.Fao.Org Retrieved $26^{\text {th }}$ November, 2018.

FGN (2018). Nigeria's export grows at $59.9 \%$ and tax revenue also at 51\%- Federal Government, African Independent Television, 1/6/2018).

Gates, B. (2018). Speech by Bill Gates, Co-Chair of Bill and Melinda Gates Foundation at the National Economic Council, Aso Rock Villa, Abuja, 22 March, 2018 In Daily Trust, 22 March, 2018, https://dailytrust.com.ng. Retrieved 12th January, 2019.

Gerth, H. H. and Mills, C.W. (1974). From Max Weber, Essays in Sociology, London: Rutledge and Kegan Paul.

Giddens, A. (2009). Sociology, $6^{\text {th }}$ edition, Cambridge: Polity Press.

IFAD (2016). Human Development Report, 2016. https://www.ifad.org Retrieved 3rd March, 2019.

Kotak, C. P. (2015). Anthropology, Appreciating Human Diversity, New York, Mc Graw-Hill.

Murdock, G. P. and Provost, C. (1973). Factors in the division of labor by sex: A Cross-Cultural Analysis Ethnology, 12 (2): 203-225.

Okafor, E. (2012). The Nigerian Economy in Peoples and Cultures of Nigeria. (Eds.) Jegede, A. Olutayo, O, Omololu 0 . and Owumi B. Ibadan: University of Ibadan.

Olawale, S. (2018). Problems of agriculture in Nigeria and solutions. https://naijaquest.com/problems.

Osikoya, O. (2016). Agribusiness, the Next Frontier, Thisday, Friday, March, 25, 2016.

Otite, O. and Ogionwo, W. (2006). Introduction to Sociological Studies, Ibadan: Heinemann Books.

Oxfam International (2017). Inequality in Nigeria, exploring the derivers, Oxfam in Nigeria, www.oxfam.org Ozo-Eson, P. I. (2012). African Society and Culture, our Heritage. Abuja: Ugwu Publishing Co. 
Okwuwa, C. O. (2019). The Imparative Of Repositioning Nigeria's Development Initiative Through Agriculture, The Neglected Path. Advances in Social Sciences Research Journal, 6(5) 250-264

Patrick-Akpan, J. (2017). Issues 2, Financial inclusion in Nigeria: the untapped opportunities, Zenih Economic Quarterly, Vol. 13, No.3, pp. 36-43.

Raj, A. (2012). Industrial Sociology; New Delhi: S.K. Kataria and Son.

Sanusi, L. (2010). The Pillars of sustaining Nigeria's economic growth prospect", speech delivered at the Igbinedion University Eight Convocation ceremony, Okada, Edo State, November 26, 2010.

Smith, B. D. (2018). The transition to food production. https//link.springer.com. Retrieved 27th November, 2018.

Ugboaja, P. K. N. (2005). Traditional African economic system" In (Ed) Ajayi, S. A. African culture and civilization, Ibadan: Heinemann Educational Books Nig. Ltd.

UN (2015). Transforming Our World, the 2030 Agenda for Sustainable Development, A/RES/70/1. UN.sustainabledevelopment.org Retrieved 2/2/2018.

UNESCO (2016). Human Development Report, 2016, hdr2016_technicl_notespdf

UNICEF (2016). The State of the World's Children, UNICEF's annual flagship report, NewYork: UNICEF, released on 28th June, 2016.

Vanguard (2018). Nigeria overtakes India as world's poverty capita.-report, 25/6/2018

https//wwwvanguardngr.com.

WEF (2017). The Inclusive Growth and Development Report (2017). WEF_IncGrwth_2017.pdf

Wikipedia (2018). The Free Encyclopedia, en.wikipedia.org/wiki/Nigeria retrieved 1/1/2018. 